UDC 37.046.16:004=111

\title{
A MODEL FOR TEACHING SPEAKING ENGLISH FOR SPECIFIC PURPOSES (INFORMATION SECURITY) USING BUSINESS GAME
}

\author{
S. S. Kolomiets, L. O. Konoplenko \\ Kyiv, National Technical University of Ukraine \\ "Kyiv Polytechnic Institute" \\ svitlanak29@gmail.com,konoplenko_lyudmila@yahoo.com
}

\begin{abstract}
While teaching English for specific purposes (ESP) at the university, it is important to find the ways to increase students' intrinsic motivation, so that they understood why it is important for them to learn the foreign language and how they might use their communication skills at work. A model of teaching English using business game developed for students whose speciality is connected with information technologies (IT) and information security is analysed in the article. The model is based on task-based learning and interdisciplinary connections of different cycle disciplines: "English for specific purposes" and "Information security quality assurance technologies", thus providing situations that might occur in students' professional life. The business game, which includes simulation of eight business meetings adapted from Agile software development methodologies and project management framework Scrum, was implemented in teaching English for specific purposes to third year students of the institute of physics and technology, National technical university of Ukraine "Kyiv polytechnic institute". The article outlines the stages of the business game (preparation, business game itself and feedback) and its framework. Procedure of calculating time allotted to the business game is described and justified.
\end{abstract}

Key words: business game, English for specific purposes, information security, task-based learning, Scrum, business meetings, integrated learning.

Introduction. Limited number of hours allotted to the subject "English for specific purposes" requires finding ways to intensify training, compress loads of language items that students might need in their future work. We would like to emphasize the importance of focusing on skills-based versus knowledge-based educational paradigm recommended by Common European Framework of Reference for Languages [9].

A number of works is devoted to teaching students of different specialities, such as "Cybernetics", "Management of information systems", "Applied Informatics in Economics" and so on.

S. Dyudyakova [3] offered to teach students basic concepts of information sciences in foreign language for effective reading manuals. I. Chirva [8] taught future software engineers questioning using computer programs. Y. Bulakhova [1] proposed integrated multimedia use. L. Salna [5] developed an algorithm for organizing a conference in foreign languages for the third and fourth year students. O. Synekop [6] created an interactive course for teaching writing using mind maps and Wikiresources. V. Strilets [7] focused on teaching reading and writing, implementing a project to create a site with a focus on its content. We consider the implementation of such projects to be a good foundation for the transition to more advanced learning technologies such as business game as they lay the foundations of team work.

The results of these studies are undoubtedly important, but their analysis shows that the development of oral communication skills of future specialists in information security was paid insufficient attention.

Numerous papers are devoted to the business games. It is worth mentioning works in different fields of science and education. In economics these are L. Volkova's, 
M. Domozhyrova's, Iu. Druz's, N. Matveeva's research papers; in future teachers training - the works of L. Ananieva, Y. Budas, M. Vorovka; in law - researches of T. Bocharova, J. Vinokurov and L. Evdokimova; in teaching interpreters $\mathrm{N}$. Gerasimova' work; in military sphere - A. Artemyeva's investigation; in tourism works of N. Bokareva, M. Bochkareva.

So business game is implemented in training specialists in various fields, but its use in teaching English for specific purposes to future specialists of information technology and information security in terms of interdisciplinary integration is insufficiently developed; this problem requires more detailed theoretical and practical research.

The goal of this article is description of the model for teaching English speaking for specific purposes to third-year students whose speciality is connected with information security. The model was tested in the National technical university of Ukraine "KPI" and proved its efficiency [10;12].

Calculating time for the business game. In accordance with a syllabus the 3$\mathrm{d}$ year students have thirty-six classroom hours and eighteen hours of self-study. As a business game is embedded into the existing program, it is necessary to calculate time that can be allotted for teaching speaking English using business game.

In addition to the time allotted for interconnected skills of speaking and listening extracurricular time for listening authentic dialogues, reading professional authentic texts and do exercises to them to prepare for the business game should be taken into account. Writing is used as a means of control of listening skills and skills in filling the backlog according to the discussed in the simulated business meetings items.

All the time for business game can be calculated by the formula:

$$
\mathrm{T}_{\mathrm{z}}=\left(\mathrm{T}_{\mathrm{aud}}-\mathrm{T}_{\mathrm{T}}\right) / 2+3 \mathrm{~T}_{\Delta \mathrm{c}} / 4 \text {, where }
$$

$\mathrm{TA}$ - the time allotted for the business game; $\mathrm{T}_{\text {aud }}-$ time in the lessons; $\mathrm{T}_{\mathrm{T}}$ time for tests; $\mathrm{T}_{\Delta} \mathrm{c}$ - time allotted for self-study.

According to this formula we obtain 13 hours of time in the lessons and 8 hours allocated for self-study. Classroom hours are devoted to preparation, modeling business meetings and analysis of the business game, extracurricular time used for students to do exercises to prepare for the game and for team software development. We emphasize the importance of self-study, which greatly affects the performance of the business game in improving speaking skills.

Teaching speaking English using business game takes place in two stages: preparation for the game and its implementation which is simulation of English professional communication. We propose to allocate 5.5 lesson hours for preparation and 7.5 hours for modelling business meetings; self-study is carried out uniformly throughout the studying.

Table 1

Time allotted for teaching speaking English using business game

\begin{tabular}{|c|c|c|}
\hline Stage & \# of the lesson & Time needed \\
\hline Preparation 1 & $1-2$ & $\begin{array}{c}1: 1,5 \text { hours } \\
2: 1 \text { hours }\end{array}$ \\
\hline Business game 1 & 3 & 1 hours \\
\hline Preparation 2 & $4-6$ & $3 \times 1$ hours $=3$ hours \\
\hline Business game 2 & $7-13$ & $6 \times 1$ hours $=6,5$ hours \\
\hline
\end{tabular}


Business game implementation. Business game should consist of three stages: first, preparation, and secondly, the game itself, thirdly, analysis and synthesis (postgame reflection) [2]. In the model proposed in this paper, second and third stages are united into one. The preparation stage is provided for the students to understand the situation of communication and to learn necessary vocabulary, grammar, functional phrases; the stage of the game itself is freer speaking practice when it is also important to check how effectively students keep to the agenda and the objectives of business meetings, how they can analyse technical task.

It is worth explaining some details of the business game stages by looking at its framework. The basis for the developed business game are Agile software development methodologies and project management framework called Scrum.

In Scrum methodology typical situations, which require speaking English for specific purposes, are Sprint planning meeting, Daily standup meeting, Sprint demo and Retrospective meeting. Some authors (e.g. H. Kniberg [11]) also point to the need for Backlog refinement meeting.

The purpose of Backlog refinement meeting is to discuss the software to be developed, creating its backlog, that is a list of functions to be implemented in order of importance. Each participant of the meeting may add tasks to the backlog.

Sprint planning meeting is the beginning of the sprint. During the meeting the product (software) elements that have the highest priority are selected, then a list of tasks that must be completed within the sprint is made (Sprint backlog), the time required to complete each task is defined.

Every day the development team discusses the tasks performed during the preceding day, tasks that are planned for the current day, and problems that have arisen. This meeting is called Daily standup meeting.

At the end of the sprint demonstration of results (Sprint demo) is held.

The last business meeting is Retrospective meeting, during which the team discusses the sprint: what the advantages and disadvantages of this time period were, what is necessary to improve in the next sprint.

All the aforementioned business meetings require dialogical communication in English.

Four business meetings that are repeated in two sprints are modeled in the game, which allows you to monitor the process of software development and check speaking English skills. Note that Sprint demo and Retrospective meeting are held in the same lesson (see Fig. 1).

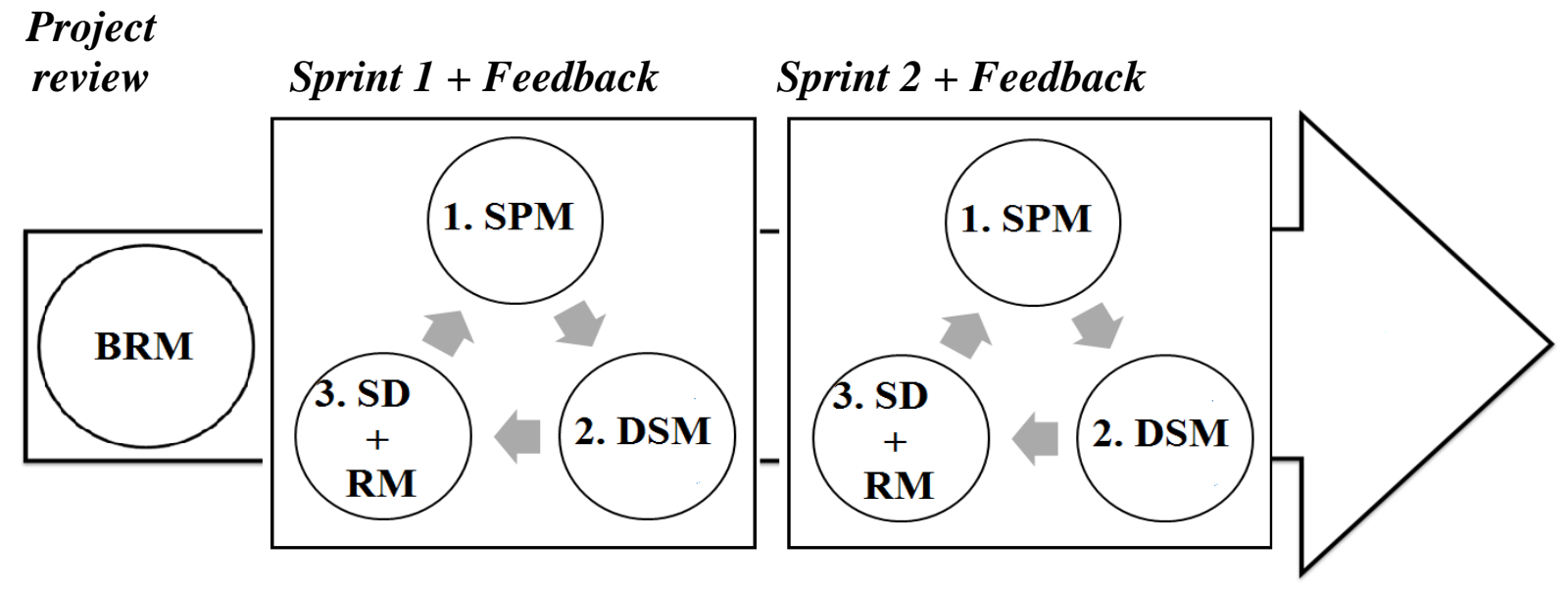

Fig. 1. Business game framework

BRM - Backlog refinement meeting, SPM - Sprint planning meeting, DSM - Daily standup meeting, $S D+R M-$ Sprint demo + Retrospective meeting. 
Preparation for the business game 1. The goal of lessons 1 and 2 is preparation for the first business meeting - Backlog refinement meeting. At this stage it is explained what business game and methodology Scrum are, and series of exercises aimed at improving the understanding of the situation of professional communication, the roles, and the stages of the first business meeting by students.

Business game 1. During the third lesson business meeting Backlog refinement meeting is modelled. Holding this meeting is essential in this session due to the professional part of the game - students must define their technical task, understand what professional topics they need to study during the semester to be able to make a presentation of their project in the process of a meeting Sprint Demo.

Preparation 2. During the fourth - sixth lessons students do exercises for improving language and speaking skills to prepare for the rest of the scheduled business meetings.

Business game 2. In the seventh - thirteenth lessons business game itself is held according to the flowchart above. Alongside with the preparation for business meetings, students are studying professionally oriented topics provided by the syllabus in "English for specific purposes" that help students to improve their lexical skills in order to describe their technical task (e.g. "Databases", "Cloud computing", "Mobile devices security"). In this paper we do not provide description of these topics and exercises because they are aimed at improving the skills of reading and writing that is not the purpose of our study.

In the business game three meetings (Sprint planning meeting, Daily standup meeting and Sprint demo) in two sprints have to be modelled. All meetings except Sprint demo are held within the group. Sprint demo meeting is aimed not only at evaluation of speaking English skills, but also at the quality of the product developed by the students (their technical task), so experts (graduates, teachers or other professionals in the field of information security) are invited.

After the Sprint demo meeting, there is the Retrospective meeting, during which students discuss the business game as a whole: what it would be better to improve, what difficulties they faced. This step helps to systematize the knowledge and experience and provide intrinsic motivation for further study. A. Nikulina [4, p. 82-87] examines the various methods of feedback. We are interested in oral, written and visual methods. Visual methods include making poster presentations with analysis of their work or use cards with embedded questions about the game. Oral methods are implemented via open class discussion. Both of the described methods can be used after Sprint demo meetings. As tor other meetings due to lack of time it is recommended to do feedback by filling in questionnaires.

The practice of speaking English provided by multiple time participation in business meetings contributes to the development of practical skills that will be needed in future career. It should be noted that the neglecting any of these stages of the business game will result in a significant reduction in its developmental potential.

Conclusion. Business game, which contains professional (information technologies and information security) and business (Scrum methodology) parts, was applied to teach students of Institute of physics and technology, NTUU "KPI" and proved its effectiveness. It was embedded into the syllabus of the discipline "English for specific purposes", this way keeping the framework of traditional education. The model, which includes simulation of eight business meetings, is designed for 13 hours of classroom training and 8 hours of self-study. This model can be adapted to other technical universities depending on their syllabi.

However, we should note that the research subject is complex, so the achieved results are not enough to cover the topic of business games in technical higher 
education. Further research might be connected with more rigorous theoretical justification of interdisciplinary links and integrated learning in language training of future specialists in information security.

\section{REFERENCES}

1. Булахова Я. В. Педагогические условия обучения иностранным языкам будущих инженеров-программистов на основе мультимедийных программ.: диссертация ... канд. пед. наук: 13.00.04 / Булахова Яна Владимировна. - Луганск, 2007. - 315 c.

2. Доможирова М. А. Деловая игра в обучении профессиональноориентированному общению на иностранном языке студентов неязыковых вузов: дис. ... канд. пед. наук : 13.00.08/ Доможирова Мария Анатольевна. - СПБ, 2002. - 212 с.

3. Дюдякова С. В. Компьютерная система обучения базовым понятиям по информационным дисциплинам на английском языке студентов-будущих программистов: дис. ... канд. пед. наук: 13.00.02, 13.00.08/ Дюдякова Светлана Владимировна. - Нижний Новгород, 2006. - 177 с.

4. Нікуліна А. С. Розвиток ділової активності учнів ПТНЗ під час професійної та загальноосвітньої підготовки: навчально-методичний посібник для педагогічних працівників ПТНЗ / А. С. Нікуліна, Д. В. Паньков, І. І. Єзінова та ін.. - Донецьк: ДІПО ІПП, 2003. - 207 с.

5. Сальная Л. К. Модель обучения профессионально ориентированному иноязычному общению студентов неязыкового вуза (английский язык, специальности: 090103 «Организация и технология защиты информации» и 090104 «Комплексная защита объектов информатизации»). : диссертация ... канд. пед. наук : 13.00.02 / Сальная Лейла Климентьевна. - Пятигорск, 2007. - 193 с.

6. Синекоп О. С. Методика інтерактивного навчання англійського писемного мовлення майбутніх фахівців з інформаційної безпеки з використанням комп'ютерних технологій. : дисертація ... канд. пед. наук : 13.00 .02 / Синекоп Оксана Степанівна. - Київ, 2010. - 370 с.

7. Стрілець В. В. Проектна методика навчання англійської мови майбутніх програмістів із застосуванням інформаційних технологій: дис. ... канд. пед. наук: 13.00.02/ Стрілець Валентина Василівна. - Київ, 2010. - 276 с.

8. Чірва I. В. Методика навчання майбутніх інженерів-програмістів англійського діалогічного мовлення 3 використанням комп’ютерних програм. : Автореф. дис. канд. пед. наук : 13.00.02 - теорія та методика навчання: германські мови / Чірва Інна Володимирівна; Київ. нац. лінгвіст. ун-т. - К., 2008. - 24 с.

9. Common European Framework of Reference for Languages: Learning, Teaching, Assessment. - Cambridge: Cambridge University Press. - К. : Ленвіт, 2001. - 274 c.

10. Insights into Agile software development. Вступ до методології гнучкої розробки програмного забезпечення [Електронний ресурс]: методичні вказівки для студентів третього курсу фізико-технічного інституту до проведення ділової гри 3 англійської мови професійного спрямування. /Уклад: Л. О. Конопленко, Є. А. Коробов. - К. : НТУУ «КПІ», 2014. - 80 с.

11. Kniberg H. Scrum and XP from the Trenches. How we do Scrum [Електронний peсурс]/ H. Kniberg. - 105 p. - Режим доступу: http://www.infoq.com/minibooks/scrum-xp-from-the-trenches

12. Konoplenko L. Experimental verification of teaching speaking efficiency using business game in the field of information security / L. Konoplenko // The Advanced Science Journal. - USA: The Advanced Science Journal. Volume 2014, Issue 10. - P. 102105.

\section{REFERENCES}

1. Bulakhova, Ya. V. (2007) Pedagogical conditions for teaching foreign languages to future programmers using multimedia. (Unpublished candidate dissertation). Lugansk national T. Shevchenko university. [in Russian] 
2. Domozhirova, M. A. (2002) Business game in teaching language for specific purposes to students of technical universities. (Unpublished candidate dissertation) Saint Petersburg State Polytechnical University. [in Russian]

3. Djudjakova, S. V. (2006) Computer system for teaching basic terms of information disciplines in English to future programmers. (Unpublished candidate dissertation). Volzhskii gosudarstvennyi inzhenerno-pedagogicheskii universitet. [in Russian]

4. Nikulina, A. S., Panjkov D. V., Jezinova I. I. (2003). Development of business activity in college students during professional and general education: textbook for college teachers. Donetsk: DIPO IPP. [in Ukrainian]

5. Salnaya, L. K. (2007) A model of teaching communication in foreign language to technical university students (English, specialities: 090103 "Information protection organisation and technology" and 090104 "Complex protection of informatisation objects"). (Unpublished candidate dissertation). Tehnologicheskii institute Iuzhnogo federalnogo universiteta $v \mathrm{~g}$. Taganroge. [in Russian]

6. Synekop, O. S. (2010) Methodology of interactive teaching English writing with the use of information technologies future information security specialists. (Unpublished candidate dissertation). Kyiv national linguistic university. [in Ukrainian]

7. Strilets, V. V. (2010) Project work methods of teaching English to future programmers using information technologies. (Unpublished candidate dissertation). Kyiv national linguistic university. [in Ukrainian]

8. Chirva, I. V. (2008) Teaching English speaking using computer software to future engineersprogrammers. (Unpublished candidate dissertation). Kyiv national linguistic university. [in Ukrainian]

9. Common European Framework of Reference for Languages: Learning, Teaching, Assessment. (2001). Cambridge: Cambridge University Press.

10. Konoplenko, L, Korobov, E. ed. (2014) Insights into Agile software development: metodychni vkazivky dlja studentiv tretiogo kursu fizyko-tehnichnogo instytutu do provedennja dilovoi gry z angliiskoi movy profesiinogo spriamuvannia. Kyiv : NTUU "KPI".

11. Kniberg, H. (2007) Scrum and XP from the Trenches. How we do Scrum. Retreived from http://www.infoq.com/minibooks/scrum-xp-from-the-trenches

12. Konoplenko, L. Experimental verification of teaching speaking efficiency using business game in the field of information security. The Advanced Science Journal, 10, 102-105.

\section{С. С. Коломієць, Л. О. Конопленко. Модель навчання усного професійно оріснтованого англомовного спілкування з використанням ділової гри. \\ У викладанні англійської мови професійного спрямування в університеті необхідно шукати способи підвищення внутрішньої мотивації студентів - розуміння ними важливості вивчення іноземної мови. У статті розглядається модель викладання англійської мови 3 використанням ділової гри, розроблена для майбутніх фахівців у галузі інформаційних технологій та інформаційної безпеки. Модель заснована на проблемному підході і міждисциплінарній інтеграції дисциплін різних циклів підготовки. Ділова гра була реалізована у викладанні англійської мови для спеціальних цілей студентам третього курсу фізико-технічного інституту, Національного технічного університету України «Київський політехнічний інститут». У статті описані етапи ділової гри і іï структура. Також обгрунтовано час, відведений для ділової гри.}

Ключові слова: ділова гра, ділові зустрічі, англійська мова для спеціальних цілей, інформаційна безпека, інтегроване навчання, проблемний

С. С. Коломиец, Л. А. Конопленко. Модель обучения устному профессионально ориентированному англоязычному общению с использованием деловой игры.

В преподавании английского языка для специальных целей в университете необходимо искать способы повышения внутренней мотивации студентов - понимания ими важности изучения иностранного языка. В статье рассматривается модель преподавания английского языка с использованием деловой игры, разработанная для будущих специалистов в области информационных технологий (ИТ) и информационной безопасности. Модель основана на проблемном подходе и междисциплинарной интеграции дисциплин разных циклов подготовки. Деловая игра была реализована в преподавании английского языка для специальных целей студентам третьего курса физико-технического института, Национального технического университета Украины «Киевский политехнический институт». В статье описаны этапы деловой игры и ее структура. Также обосновано время, отведенное для деловой игры.

Ключевые слова: деловая игра, английский язык для специальных целей, информационная безопасность, проблемный подход, Scrum, деловые встречи, интегрированное обучение. 